\title{
GLOKAL REKLAM VE METAFOR: ÜNIVERSITE ÖĞRENCILERI ÜZERINE BIR ODAK GRUP ÇALIŞMASI
}

\author{
Cihan BECAN*
}

Gönderim Tarihi: 19.06.2019 - Kabul Tarihi: 11.09.2019

Becan, C. (2019). “Glokal Reklam ve Metafor: Üniversite Öğrencileri Üzerine Bir Odak Grup Çalışması". Etkileşim. 4. 130-150.

\section{Özet}

Markaların, ürün ve hizmetlerini ulusal ya da uluslararası alanda tüketicilerine sunarken mesaj stratejilerinden ambalaja, ses tonundan kullandığı dile kadar iletişim planlaması yapması gerekmektedir. Yerel olarak sunulan bir reklamın mesajı ile küresel reklamın mesajı farklılaşabilmektedir. Uluslararası ölçekte varlığını kabul ettiren kurumlar, diğer ülke pazarlarını analiz ederek, o bölgedeki tüketicilere yönelik başta reklam olmak üzere diğer iletişim faaliyetlerini düzenlemesi zorunludur. Bu bağlamda araştırmada global markaların Türkiye'de gerçekleştirdikleri glokal reklam kampanyalarında kullanmış oldukları metafor türleri ve kültürel kodlar incelenmektedir. Bu araştırmada temel amaç, global markaların Türkiye'de yayımlanan TV reklamlarında metafora ne şekilde yer verdiğini, tüketicinin reklamdaki metaforu nasıl algıladığını ortaya koymaktır. Bu amacı gerçekleştirebilmek için 2017 yılı içerisinde TV kanallarında gösterilen ve metafor içeren reklamlar seçilmiş; devamında beş kodlayıcının da uzlaştıkları üzerinde çalışılacak 12 reklam belirlenmiştir. Seçilen reklamlar için randevu alınabilen 14 öğrenciyle, odak grubu tekniğinden yararlanılarak, yarı yapılandırılmış görüşmeler yapılmıştır. Araştırma sonuçlarına göre reklamlarda kullanılan metaforlar, daha çok milliyetçilik, vatanseverlik, mutluluk, eğlence, güçlü olmak, özgürlük olarak yapılandırılmıştır. Kullanılan metaforların izleyenler tarafından algılanan anlamı ve metaforların yaratıkları duygusal çağrışımlar, araştırma kapsamındaki reklamların büyük çoğunluğunda izleyen denekler arasında benzerlik göstermektedir. İzleyen deneklerin metafora yönelik değerlendirmelerine ilişkin bulgular, büyük çoğunluğunun reklamı beğenmesi, reklama ilişkin duygusal yakınlık hissetmesi ve yaratıcılığı desteklediği yönündedir.

Anahtar Kelimeler: globalleşme, glokalleşme, glokal reklam, metafor, odak grubu.

* Doktor Öğretim Üyesi, Üsküdar Üniversitesi, Illetişim Fakültesi,

cihan.becan@uskudar.edu.tr, Orcid: 0000-0002-1289-1360 


\title{
GLOCAL ADVERTISING AND METAPHOR: A FOCUS GROUP STUDY ON UNIVERSITY STUDENTS
}

\author{
Cihan BECAN*
}

Received: 19.06.2019 - Accepted: 11.09.2019

Becan, C. (2019). “Glokal Reklam ve Metafor: Üniversite Öğrencileri Üzerine Bir Odak Grup Çalışması". Etkileşim. 4. 130-150.

\begin{abstract}
Brands are required to conduct message strategies and communication planning from packaging to language and voice of tone while presenting their products and services to their national and/or international consumers. The message of the local ad is different from the message of the global ad. Companies that have established their presence on an international scale must analyze the markets in other countries and organize advertising and communication activities for consumers in that region. In this context, this thesis investigates the metaphor types used in glocal advertising campaigns in Turkey and the cultural codes. The objective of this study is, in general, to determine how global brands have used metaphors on commercials broadcasted in Turkey and to reveal how people understand these metaphors. For this purpose, the metaphor-included advertisements shown on television in 2017 have been determined and following this, 12 commercials agreed on by 5 coders have been selected for the study. For the selected commercials, with the technique of focus-group, semi structured interviews have been held with 14 audience group. According to the results of the study, the metaphors used in the advertisements have been mostly structured on nationality, patriotism, happiness, entertainment, strengthness and freedom. The meanings of the metaphors and the related emotional associations drawn by the viewers are similar for most of the advertisements used in the study. The findings regarding the thoughts of viewers about metaphors demonstrated that metaphors cause most viewers to fancy the advertisement, to have good feelings for the advertisement and to think that they support creativity.
\end{abstract}

Keywords: globalization, glocalization, glocal advertising, metaphor, focus group.

* Lecturer/PhD, Üsküdar University, Faculty of Communication, cihan.becan@uskudar.edu.tr, Orcid: 0000-0002-1289-1360 


\section{Giriş}

Globalleşme, daha önce ekonominin ve toplumun ulusal özelliklerinin cereyan ettiği ülkelerde ekonomik, sosyal ve kültürel normları, alışkanlıkları ve ilkeleri bir araya getirmekle kültürel bütünleşmeyi ve birleşmeyi içine alan bir süreçtir. Gelişen teknoloji ile yaşam standartları şekillenen toplumlar globalizasyon kavramı altında ortak bir kültürün esaretine geçmiştir. Bununla da ulusaşırı işletmeler, globalleşme gayretleri içinde olmalarının sonucu olarak, dünyada farklı ülkelerin ekonomik piyasalarına girebilmek için çaba sarfetmek zorunda kalmışlardır.

Globalleşme sürecinin beraberinde getirdiği global reklam anlayışı da, çağımızda faaliyeti ulusal sınırları aşan şirketler için etkili reklam türü olma özelliğini kaybetmiştir. Bu nedenle global düşünülüp ortak ve yaygın mesajlar üretilmesine rağmen izleyiciye verilmesi hedeflenen mesajlar ülkelere göre değişim göstermektedir. Bu da glokal reklam anlayışının gelişmesine zemin hazırlamıştır.

Glokal reklam stratejilerinin gerçekleştirilmesi için ulusaşırı işletmelerin hayata geçirdiği reklam çalışmaları ülke kültürlerine has dil, gelenek ve görenekler gibi kültürel kodları kullanarak farklı ülkelerin pazarlarına girmeyi hedeflemişlerdir. Bu yönde yürütülen reklam çalışmaları ile gelinmek istenen nokta, ülkelerin kendilerine has, yerel kültürlerini ortadan kaldırmak ve global modernizm bağlamında, batı kültürünü yaygınlaştırmaktan ibarettir.

Bu çalışma özellikle uluslararası markalar tarafından yayımlanan reklamlar aracılığıyla tüketim kültürünün nasıl küre-yerelleştiği konusuna ışık tutmaktadır. Bunun yanı sıra temel itibariyle kültürel imgelerin reklamlar üzerinden, ürünlerindeki statü, kimlik algısı ve itibar gibi unsurların topluma nasıl etki ettiğini ve bu etkinin tüketime yansımasını ele almaktadır. Çalışma konusunun seçilmesinin bir diğer önemi, son birkaç yıldır gelişim gösteren reklam sektöründe kültürel unsurların metaforlar üzerinden etkisini anlamaktır.

Çalışmada Türkiye'de faaliyet gösteren global markaların, yayımladıkları glokal reklamlarda kullanılan metaforların ortaya çıkarılması amaçlanmıştır. Bu amaç doğrultusunda YouTube ortamında yayımlanmış olan televizyon reklamları seçilerek metafor ve yerel semboller, nitel analiz tekniklerinden biri olan odak grup çalışması kapsamında incelenmiştir.

\section{Kavramsal Olarak Glokalleşme ve Glokal Pazarlama}

Türkçede "küresel" ve "yerelleşme" sözcüklerinden oluşan küyerelleşme, son zamanlarda yaygın olarak benimsenen ve kullanılan kavramlardan biridir. Küresel ve yerel olanın eşanlılığı yeni bir kavram arayışına itmiştir. Bu görüş ilk olarak çiftçilik tekniklerini yerel koşullara uyarlamanın tarımsal ilkesi olan, Japoncada insanın kendi toprağında yaşaması anlamına gelen "dochakuka" kelimesinden türemiştir. Global bir bakış açısının yerel koşullara uygunlaştırıldığı 
global lokalleşmeye yönelik olarak Japon iş dünyasına kabul ettirilmiştir. Robertson, eşanlılığı vurgulamak için, Japon iş dünyasında yerel koşullara uyarlanan "küresel taslak" anlamındaki "dochakuka"dan hareketle "glokalleşme" kavramını önermiştir (Balcı, 2006: 31).

Glokalleşme kavramı ticari bakımdan bazı bağlamlarda söylenildiği gibi mikro pazarlama ile doğrudan doğruya bağlantılıdır. Küçük ölçekli pazarlama (mikro pazarlama) veya daha kapsamlı söylemek gerekirse glokalleşme kavramı, önemli derecede ve giderek artan bir şekilde birbirinden farklı tüketicilerin ortaya çıkışını gerektiren bir süreçtir. Daha basit olarak, farklıı̆ın tüketiciye sunulduğunu işaret etmektedir. Yani ürün ve hizmetlerin gitgide farklılaşan yerel pazarlarda global ya da globale yakın bir temelde uygunlaştırılıp tanıtılmasını içermektedir (Robertson, 1999: 29). Glokalleşme kavramı, "global pazar için üretilen ürün ve hizmetlerin yerel kültürlere uyacak biçimde sunulması" anlamına gelmektedir. Lokalleşme olgusunun öneminin artması ile birlikte global ve lokal kavramlarının birleştirilmesiyle ortaya çıkan "glokalleşme" kavramı geniş ölçüde benimsenmiş ve kullanılmaya başlanmıştır (Arslan, 2016: 68).

Bir başka tanıma göre glokalleşme, küresel pazara yönelik ürün veya hizmetlerin yaratılması, ancak yerel kültürlere uygun hale getirilmesi anlamını içermektedir (Khondker, 2004: 15). Robertson (2011: 188) glokalleşme sürecini düşünsel ve daha açık bir şekilde ekonomik terimlerle küçük ölçekli pazarlama ile yakından ilişkili olduğu konusunda gönderide bulunarak, mal ve hizmetlerin giderek farklılaşan yerel ve tikel piyasalara global ya da globale yakın bir temelde uyarlanarak tanıtılmasını öne sürmektedir. Maynrad (2003: 60) ise glokalizasyonu, global şirketlerin tüketici taleplerindeki farklılıkları karşılamak için ürünlerin ve pazarlamanın belirli yerel koşullara göre uygun hale getirilmesi süreci olarak ifade etmektedir. Glokalleşme, kısaca "uluslararası ilişkilerde global gerçeklerden hareket ederek global düşünmeyi, dünya ekonomisi ile bütünleşmeyi; ülke içinde ise merkezi yönetim kanalıyla ekonomiyi ve siyaseti yönlendirme yerine yerel yönetimleri daha fazla güçlendirmeyi" ifade etmektedir (Aktan, 1998: 15).

Glokalleşme, yakın zamanda ortaya çıkan farklı ve yeni bir dönemin başlangıcıdır. Bu dönemde geleceğin pazar segmentlerinin daha odaklanmış ve daha küçük olacağı, mümkün olan en küçük hedef pazar düzeyine, yani bireysel müşteri düzeyine indirgeneceği anlaşılmaktadır. Bu nedenle yeni gündemin iyi değerlendirilmesi, kültürel farklılıkların ve müşteri beklentilerinin iyi anlaşılması ve pazarlama stratejilerinin buna göre yeniden şekillendirilmesi gerekmektedir. Bu suretle henüz keşfedilmemiş yeni pazarlara erişilmesi mümkün olabilecektir (Arslan, 2016: 69).

Glokalleşmeye yol açan faktörlere ilişkin olarak, temelde belli başlı unsurlar üzerinde durulduğu görülmektedir. Globalleşmeyi hızlandıran önemli unsurlar arasında, iletişim ve bilgi teknolojilerindeki hızlı gelişmeler, bilgisayarın ve internetin yaygınlaşması, ulusal ve uluslararası ticaret ağlarının genişlemesi, yabancı yatırımların ve uluslararası şirketlerin artması gibi temel gelişmeler 
sayılabilir. Glokalleşme sürecinin hızlanmasıyla, işletmenin faaliyet alanları, rekabet şekilleri, örgütsel yapıları ve yönetim anlayışları değişmeye başlamıştır. Artık sadece yerel ülke içerisinde veya çok sınırlı bir uluslararası çevrede gösterilen faaliyetlerin etkisiyle mücadele etmekten öte, glokal bir pazarda ve glokal rakiplerle mücadele zorunluluğu doğmaktadır. Böylece glokalleşme kavramı, bir ürünün globalizasyon oluşumu içinde her bir yerel bölge için uygun hale getirilmesi ve böylelikle başarılı olma ihtimalinin daha yüksek olacağını belirtmek amacı ile oluşmuştur. Ulusötesi şirketler bu nedenle yerel duyarlılık ve pazar anlayışını, faaliyet gösterdikleri ülkelerdeki ulusal farklılıkların ve yerel çıkarların farkında olmak zorundadırlar.

Glokal pazarlama, global markaların belirli ülkeler için hazırladıkları ve sadece o ülkeye özgün motiflerin, özelliklerin kullanıldığı ve bu sayede pazarlaması yapılan ürün ya da ürünlerin söz konusu pazarlarda konumlandırılmaya çalışılmasıdır. Glokal pazarlama, global ya da lokal pazarlamaya karşı olan bir pazarlama şekli değildir ve glokal pazarlama çabaları, global pazarlama stratejilerinden ayrı düşünülemez. Glokal pazarlama yaklaşımı, yaşanan değişimlere ve şiddetlenen rekabet koşullarına zamanında ve mantıklı bir çözüm olarak sunulmuştur (Champy, 1997). Bu yaklaşımda, sadece belirli bir ülke ya da bölgeye özgü yeni bir ürünün hazırlanması ve bununla ilgili pazarlama stratejilerinin uygulanması amaçlanmaktadır. Ancak, lokal anlamda bazı temaların kullanımı gerekli olsa da o ürün, hizmet ya da markanın dünyanın her yerinde birbirini tamamlayan bir yapıda sunulması gerekmektedir. Bu nedenledir ki zaman zaman global pazarlar için hazırlanan bir ürün, farklı bir ülkede aynı imaj ile pazarlanmaya çalışıldığında yeterli kabulü görmeyebilmektedir. Bu yüzden glokal pazarlama çabaları içinde en önemli unsur, ayrıntılı bir analiz ve bu analizlere göre hazırlanacak pazarlama stratejilerinin uygulanması olmaktadır.

Örneğin McDonald's, ürünlerini dünyanın diğer bölgelerindeki belirli müşteri zevklerine göre düzenleyerek denizaşırı ticaretini başarıyla genişletmiştir. $A B D$ dışındaki McDonald's menüsü $A B D$ 'deki menüden oldukça farklı şekilde sunulmaktadır. Tokyo'daki bir McDonald's yerel menü doğrultusunda; karides külçelerini, yeşil çay dondurmasını ve patates püresi, lahana ve katsu soslu 'Koroke Burger'i sunmaktadır. Bir fast food restoranında glokalleşme, ürünleri ve menü değişiklikleriyle bu şekilde gerçekleşmektedir. Ancak glokalleşme, diğer ticari faaliyetlerle de kendini göstermektedir. Günümüzde glokalleşme, kendini "dünyanın yerel bankası" olarak nitelendiren HSBC ve "dünyanın yerel restoranı" tanımlaması kullanan McDonald's gibi uluslararası şirketlerin reklam söylemlerinin bir parçası haline gelmiştir.

\section{Küresel Markaların Yerel iletişim Stratejisi Olarak Glokal Reklam}

Şirketlerin pazarlama hedeflerine ulaşmasında pazarlama karmasının öğeleri olan fiyat, ürün, dağıtım ve tutundurma karmasının rolü son derece önemlidir ve bunlar müşterilere firmaların ürünü ve hizmeti ile ilgili bütün ayrıntıları sergilemektedirler. Bu nedenle, bütünleşik pazarlama iletişimi çalışmalarından 
olan reklamlar, tutundurma karmasının diğer unsurları gibi işletmenin pazarlama hedeflerine ulaşması ve bu istikamette karşılaşılan problemlerin çözülmesinde de başlıca görevlerden birini üstlenmektedir.

Reklam, kültürel anlamı sosyal çevrelerden ürünlere aktarma konusunda en fazla başvurulan bir iletişim yöntemidir. Reklam, yalnızca ticari bir etkinlik olarak kalmamakta, aynı zamanda farklı görevler de üstlenen bir iletişim türüdür. Reklamcılığın toplum kültürüne olan etkisi de bireylerde birçok alışkanlıkları değiştirebilmektedir. Reklamcılık fonksiyonel bir dil kullanmakla tüketicileri harekete geçirmeyi amaçlamaktadır. Bu noktadan bakıldığında, iletişimde gönderilen mesajların bireylere ulaşma şekli özenle seçilmelidir. Bunu göz önünde bulundurarak reklamlarla, tüketicilerde iyi bir etki uyandırmak ve onların dikkatini çekebilmek için çeşitli yöntemlere başvurulmaktadır (Sığırcı, 2016: 117).

Baudrillard'a göre (2008) reklamcılık, toplumsal iletişim şeklidir. Reklam verenler kimlik ve prestij yaratmakla yaşam tarzlarını, sembolik değerleri ve zevkleri bir bütün olarak birleştirip gerçekleştirmektedirler. Reklamlar, tüketicilerin sosyalleşmesinde ve anlamları yeniden üretmelerinde önemli kavram sistemleri oluşturmaktadırlar. Bu şekilde bireylere popüler olabilmek için ne yapmaları gerektiğini göstermekte ve belli ürünleri satın almaları için ikna etmektedirler. Reklamlar bir yandan tüketicilere, sundukları değerler vasıtasıyla rol modeller ve sosyal davranışlar öğretirken, yapılan değişikliklerle tamamen yeni bir insan haline getirmektedir. Bu şekilde reklam, tüketim talebini yönlendirici olduğu kadar toplumsallaşma aracı işlevini de üstlenmektedir (Kellner, 2001: 214).

Globalleşme ile beraber önem kazanan global reklam kavramı ise günümüzde uluslararası alanda faaliyet gösteren işletmeler için tek ve geçerli reklam çeşidi olma özelliğini yitirmektedir. Çünkü ne kadar global düşünülse ve genel mesajlar verilmeye çalışılsa da aktarılmak istenen mesajlar ülkeden ülkeye değişiklik gösterebilmekte ve bu mesajların anlaşıımasında bazı farklılıklar olmaktadır. Bu gelişmeler doğrultusunda reklam çeşitleri içine glokal reklam kavramı da girmiştir. Glokal reklamla, global anlamda genel bir konsept ve hedeften ayrılmadan reklamın yapıldığı ülkeye özgü yerel özellikleri de içinde barındıran reklamdan bahsedilmektedir. Yani günümüzde global markaların belli ülkelerde, o ülkelerin kendine has motiflerini kullanarak reklamı yapılan ürünü söz konusu pazarlarda konumlandırmaya çalışması karşımıza glokal reklam kavramını çıkarmaktadır (Elden, 2005: 64). Global markaların yerel pazarlara girmesi durumunda uygulanması gereken glokal reklam stratejileri konusunda daha hassas ve dikkatli davranması gerekmektedir. Global markaların pazarlama iletişiminde başlıca unsur olan reklamlar ve kullanılan stratejiler markaların tüketicilerin zihnine kazınmasını, akılda kalıcılı̆ını sağlamaktadır. Reklamlar genel anlamıyla bireylerin sosyal hayatta yeni davranış alışkanlıkları kazanması için ürünler üzerine sembolik anlamlar yükleyerek ürettikleri duygu ve değerlerle tüketicileri mıknatıs gibi kendisine çekmektedir. 
Yaratıcılık anlayışı glokal reklam kampanyalarında global reklamlardan farklı olarak daha ön plana çıkmaktadır. Global pazarlama kararları stratejik seviyede firmaların tüm dünyayı tek bir pazar olarak kabul etmesi ile uygulanırken, glokal pazarlama stratejileri işletmeler tarafından hem operasyonel hem de taktiksel seviyede uygulanabilmektedir (Kazançoğlu vd. 2011: 69). Global markalar kendi imajını farklı ülkelerin yerel motiflerine uygun bir şekilde tanıtığı gibi o ülkelerde pazara girebilmek için yerel kültürel özelliklerle ürettiği ürünleri de glokal reklam kampanyalarıyla biçimlendirmesi kaçınılmazdır. Glokal pazarlara girerken ülkelerin pazar yapısını analiz etmekle beraber, o toplumun kültürel değerlerini, dil yapısını da iyi derecede incelemek gerekmektedir. Fakat sadece bunlar yeterli değildir. Hazırlanan çalışmalarda bunlara uygun, anlaşılır bir yaratııılık kullanmak gerekmektedir. Bu noktada global reklam çalışmaları içinde yer alan glokal reklam çalışmalarının da önemi yadsınmamakla beraber reklamı yapılan markanın temel stratejilerinden ayrılmayacak şekilde, seslenilen ülkeye uygun bir yaratıcılıkla reklamların hazırlanması gerekmektedir (Okay, 2015: 60).

Chiu ve diğerleri (2012: 5) yerel kültürün tüketici davranışlarını nasıl etkilediğini anlamak için yerel motifleri ve öğeleri çok iyi derecede araştırmak gerektiğini, bunun tüketici davranışlarındaki kültürlerarası farklııkların yanı sıra kültürler arasındaki benzerlikleri ve farklılıkları da anlamaya yardımcı olduğunun altını çizmektedir. Yapısal ve kültürel olarak birbirinden farklı coğrafyalarda yerleşik ülkelerde reklam mesajları tüketici davranışlarının kültürden kaynaklanan farklııklarına göre oluşturulmaktadır. Örnek olarak, Burger King markasının Türkiye'de Ramazan aylarında teklif ettiği "sultan menü" veya Haribo şekerlemelerinin televizyon reklamlarında müslüman ülkeler için "helal Haribo" ifadesini kullanması, ürünün domuz yağı içermediğine dikkat çekmesi, tam olarak kültürel değerler ve farklılıkların gözönünde bulundurulduğunun bir göstergesidir (Aktuğlu ve Eğinli, 2010: 169). Glokal reklam kampanyası çerçevesinde reklamda ses ve müziğe verilebilecek güzel bir örnek Türkiye'de Ramazan ayında yürütülen iletişim çalışmalarıdır. Kitle iletişim araçlarına sunulan reklamlarda Ramazan ayını temsil eden görsel öğelerin yanı sıra davul sesi gibi efektler ve farklı dini melodiler sıklıkla kullanılmaktadır. Bunlar sonucunda pazarlama iletişimi stratejisi doğrultusunda hazırlandığı ve markaların o aya özel iletilerini ses üzerinden de taşıdıkları güçlü olarak görülmektedir (Yaman, 2015: 7).

Glokal reklam çalışmalarında reklamcının kültürler arasındaki farklılıkların ayrıntılarına ilişkin farkında olması gerekmektedir. Renkler, sözel olmayan iletişimde iletileri aktarmanın en hızlı yollarından biridir. Renklerin farklı kültürlerde farklı anlamlar ifade ettiği fikrine dayanarak örneğin, yeşil rengin Müslümanlarda "din yandaşlığı"nı simgelediğini, fakat Avrupa ülkelerine döndüğümüzde bu rengin "çevreciliği" simgelediği karşımıza çıkmaktadır. Glokal pazarlama yöneticileri siyah rengin batı ülkelerinde yas rengi sayıldığını, bazı Asya ülkelerinde beyazın yas rengini simgelediğini bilmelidirler. Yeşil renk genel olarak serinlik anlamını içeren bir ürünün tanıtımında kullanılsa da, tropik 
bölgelerde yaşayan insanlar için yeşil, hastalık ve tehlike anlamını açıklamaktadır. İtalyan bayrağının renkleri olan kırmızı, beyaz ve yeşili bazı italyan yiyeceklerinin ambalajlarında da görmek mümkündür veya ABD'de meşrubatlar kırmızı renkle bağdaştırılmıştır. Fakat Coca Cola'nın kurumsal rengi olan kırmızının Kore ve Japonya'da kullanılması sorun olmuştur. Bunun nedeni ise bu ülkelerdeki meşrubatla çağrıştırılan rengin sarı olmasıdır. Bu şekilde, reklam mesajlarında kullanılan renklerin farklı ülkeler için farklı kültürel anlam ifade etmesinden ötürü, reklam stratejisi belirlenirken hangi ülkede hangi rengin ne anlama geldiğinin yadsınmaması gerekmektedir.

\section{Bir Anlatım Biçimi Olarak Metafor}

Metafor kelimesi Eski Yunanca'da, öteye taşıma, nakletme anlamını ifade eden metapherein'den gelmektedir. Retorik yazarları metaforu, translatio veya transferentia'ya dönüştürmüşlerdir. Anlamı bir şeyin (sadece sözcükler değil) bir yerden başka yere taşındığı bir şema ile karşılaştırılmaktadır. Buradaki "gerçek" metafor ise ortaya çıkan yer değiştirmedir. Yani elimizde mevcut bulunan bir şeyin, ele alınamayacak bir şekilde mevcut olmayan veya burada hazır olmayanın yerine geçmesidir (Karamehmet, 2012: 34). Eraslan (2011: 3) kavramın Türkçede karşılığının benzetmeler, eğretilemeler ve mecazlar olarak kullanıldığı görüşündedir. Etimolojik yapısı metaforu, bir olguyu veya nesneyi yeniden kavramsallaştırma, farklı taraflarıyla ilişkilendirme ve anlatma özelliğini öne çıkarmaktadır.

Forceville'e (1996: 35) göre metafor, beklenen bir görsel öğenin, beklenmedik bir görsel öğeyle değiştirilmesidir. Lakoff (1993: 210) ise metaforları, nesnelerin anlama alışkanlığını genişlettiğini ve çeşitli özgün anlamlar üretebildiğini öne sürmektedir. Metaforlar genel olarak insanların kendi deneyimlerine dayalı olarak ortaya çıkmakta, anlatılan ve benzetilen iki anlam arasında algılanan benzerlikleri ortaya çıkarmaktadır. Ayrıca bir metaforun bir konuşma şekli değil, bir düşünce biçimi olduğu ileri sürülmüştür. Ziss (1984: 292) Estetik isimli eserinde metaforu şu şekilde tasvir etmektedir: "Metafor, sanatçının düşüncesinin nesnesini, duyularla algılanabilen dünyanın nesnelerine ve olaylarına benzetme olanağı sağlayan yöntem; dışsal benzer özellikleri olan iki olayın, birinin içsel özünü, ötekinin yardımıyla gün yüzüne çıkarmak için sanatsal olarak karşılaştırılmasıdır".

Nietzsche (2002: 506) son eserlerinde metafor kavramını ortaya çıkaran sürece ilişkin görüşlerini şu şekilde belirtmektedir: "ilkin hayaller-imgelerin zihinde nasıl meydana geldiğini açıklamak gerekir. Bundan başka imgelere uygulanan sözcükler, sonunda eğer sözcükler varsa, ancak o zaman kavramlar oluşur". Bu çıkarımdan yola çıkarak, Nietzsche'nin kavramın yalnızca metaforun metaforu olduğunu ileri sürdüğü ve birlikte anlatılmak istenenin üçüncü taraftan temsili olduğunu savunduğu kanısına varılmaktadır. Metafor, yeni bir olayı veya olguyu anlamak ve yorumlayabilmek, dolayısıyla bilginin öğrenilmesini kolaylaştırma işlevini ortaya çıkarmaktadır. Metaforlar hakikatin inşasıyla 
beraber onun nasıl görülmesi gerektiği konusunda da bilgi verebilmektedir (Yıldırım, 2001). Bu değerlendirmeler ışığında genel olarak metafor kavramının işlevlerini; benzer kavramlar arasında oluşan, bir ifadenin anlatım şeklinden diğerine transfer olunan, özünde bağlantısız olan iki nesne arasında ilişki kurabilen, edinilen bilgiyi farklı türlerde gösterebilen olarak söylemek mümkündür.

Düşünce ve öğrenme sürecinin bir parçası haline gelen metaforlar, bir dilbilimsel mecaz (benzetme) olmakla kalmayıp, aynı zamanda dış dünya ve dilin bilişsel şekilde kavranması sürecinde de sıklıkla kullanılmaktadır (Pawlowski vd. 1998: 83). Lakoff ve Johnson (2005: 25) ise bu konuda metaforu sadece dilin karakteristiği gibi bir izahtan kaçınmış, metaforu bir tür nesneyi başka bir tür nesneye göre ifade etmek görüşünü savunmuştur. Örneğin, "zaman paradır" ifadesinin metaforik anlatım tarzına dikkat edildiğinde, zamanın da harcanabilir olması, zamana da yatırım yapmanın mümkün olduğu ve bunun gibi bu iki sözcüğü tamamlayan diğer anlamlar da çıkarılabilmektedir. Fiske'nin (2003: 126) de belirttiği üzere, yazarlar burada parayı zamanın bir eğretilemesi olarak vurgulamaktadır. Zamandan "tasarruf etmek" veya bir projeye zaman "yatırımı yapmak" hususundan bahsedildiğinde zamanı paraymış gibi düşünmek söz konusu olmaktadır. Zaman, şüphesiz ki paradan farklı bir anlam taşımaktadır; tasarruf edilemez, bir insan diğerinden daha fazla zaman biriktiremez yahut daha fazla zaman kazanmak için yatırım yapılamaz. Bu metafor örneğinde para, zamanın bir eğretilemesi olarak kullanılmıştır.

Lakoff ve Johnson (2003), metaforu sadece bir dil meselesi olarak değil, aynı zamanda bir düşünce meselesi olarak görmekle beraber, çağdaş metafor çatısı altında; ölü metafor, somut metafor, soyut metafor, ontolojik metafor ve yön metaforu olmak üzere beş farklı metafor türünden bahsetmektedir. Zaman geçtikçe metaforların ifade ettiği anlam kökenlerinden kopabilmekte ve dilde artık özümsenmiş bir kelime olarak kullanılabilmektedir. Örneğin, "Masanın ayağı, meselenin özü, politikanın nabzı, dağın eteği, içi acımak, içine sindirememek vb. gibi metaforlar, öylesine uzun zamandır kullanılagelmiş ve öylesine sıradanlaşmışlardır ki benzeyenle benzetilen (taşıyıcı) arasındaki çakışmazlığın farkına varamayız" (Salman, 2003: 53). Bu düşünceler ışığında ölü metaforların, sık kullanım ya da modası geçmiş terminoloji aracılı̆ı̆ıla orijinal anlamını kaybeden, hayal gücünü zorlayan bir anlatım şekli olduğunu söylemek mümkündür. Morgan ve Reichert (1999: 4) metaforların kavramlar arasındaki karşılaştırmanın doğrudan deneyimlenebileceği dereceye dayanan soyut ve somut metaforlar olarak birbirinden ayrıldığına dikkat çekmektedir. Somut metaforlar doğrudan deneyimlenebilen, yani beş duyudan gelen karşılaştırmalara dayanan metaforlardır. Soyut metaforlar ise doğrudan deneyimlenemeyecek karşılaştırmalar içermekte, maddi olmayan nesnelere dayanmaktadır. Örneğin, Concord markasının sunduğu saat reklamına bakıldığında, saatin ismi "Grace" yani zarafettir. Reklam çalışmasında sunulan karşılaştırma, saati belirli bir özellik ile beraber tutmaktadır. Zarafet doğrudan tecrübe edilemeyen, yani dokunuş, tatma, koklama ve duyma yoluyla deneyimlenemeyen bir durumdur. 
Ontolojik metaforlar maddi olmayan herhangi bir varlı̆̆ fiziksel bir nesne gibi açıklayan metaforlardır. Lakoff ve Johnson (2003: 29) "Metaphors We Live By" isimli çalışmasında ontolojik metaforlardan bahsederken, onları nesnelerin açık bir şekilde maddi veya sabit olmadığı durumda somut adları ile yani dağlar, cadde köşeleri, çitler vs. olmakla sınıflandırmışlardır. Dağlara yerleşmek, cadde köşelerinde buluşmak, çitleri düzeltmek insani amaçlar olmakla, somut nesneleri insanların farklı olduğu gibi değişik fenomenler, bir başka deyişle bir yüzey tarafından sınırlanmış varlıklar haline getiren yapay sınırlar koymalarını gerektirmektedir. Dolayısıyla, ontolojik metaforlar fiziksel objelerdeki tecrübelere dayanmaktadır. Kavramların birbiriyle mekansal anlamda bağlantılı olduğu metafor türleri ise 'yön metaforları' olarak adlandırılmaktadır (Kövecses, 2010: 41). Mekansal oryantasyon ile bağlılığı olduğu için onları bu işleve hizmet eden yukarı-aşağı, içeri-dışarı, ön-arka, beri-öte, derin-yüzey, merkez-çevre olarak adlandırmak mümkündür. Bu işleve hizmet eden çoğu metafor mekansal yönelimleri ile ilgili olduğu gerçeğinden kaynaklanmaktadir.

Metafor kullanımı, tüketicilerin hayal gücüne odaklandığı için pazarlama iletişimcileri ve yöneticilerinin üzerinde sık durması gereken bir konudur. İşletmenin reklam çalışmalarında kullandığı metaforlar, bireylerin aldıkları iletileri nasıl değerlendirdiğini ya da herhangi bir ürünün gerçek değerini hangi biçimde algıladığını etkilemektedir. Metaforlar doğru bir şekilde seçilirse ve kullanılırsa, tüketiciler reklam metninde aslında gösterilmeyen bilgileri alabilmektedirler. Zaltman (2003: 139) bu vakaya örnek olarak, tüketicilerin bir koalanın gösterildiği reklamı izlediklerinde içeceğin ılık şekilde içilmesi gerektiğini düşüneceklerini söylemektedir. Buna karşıt, reklamda kutup ayısını gören tüketici ise içeceğin soğuk şekilde içilmesi kanaatine varacaktır. Söz konusu reklam çalışmasında doğru metafor seçilmemesi, koala ayısı içeren reklamda soğuk içeceğin reklam olunması neticede tüketicilerin kafasını karıştırmıştır. Reklam her zaman yan anlamları, metafor unsurları içeren bir iletişim şekli olmuştur. Reklamlar çoğunlukla düz anlam kullanılmak yoluyla anlatılmamaktadır.

Reklam filmlerinde metafor kullanılmasından beklentiler tüketicilerin ilgisini çekmek, ürünün akılda kalıcılığını arttırmak ve sonuç olarak tüketiciyi satışa yönlendirmekle hedefe ulaşmaktır. Reklamlarda ve pazarlama iletişiminde görsel metaforlar sıklıkla kullanılmaktadır. Bundan başka reklam başığında, sloganında veya reklam metninde de metaforlara yer verilebilmektedir. Ang vd. (2006: 40) reklamlarda metafor kullanımının avantajlarını aşağıdaki gibi sıralamaktadır:

- Metaforlar, reklam mesajlarının tüketiciler tarafından beğenilirliğini arttırır. Metaforlar edebi mesajdan daha çok bilişsel bir ayrıntı oluşturur.

- Metaforlar, yenilik ve değişiklikleri enjekte etmekle reklamı okuma ve işleme motivasyonunu arttırır. 
- Metaforların süsleme ve gizleme becerileri sayesinde marka daha iddialı algılanabilir ve reklamlara olan ilgi de bu sayede artabilir.

Reklamcıların metaforları kullanma sebebinin altında metaforların bireylerin günlük yaşantısının ve konuşmalarının bir parçası olması yatmaktadır. Örneğin, 'Sevgililer Günü'nde birisine kırmızı güller hediye etmek sevgi ve tutkuyu ifade etmektedir. Reklamcılar sevgiyi ve tutkuyu anlatmak için, reklam kampanyalarında kırmızı gülleri ya da kalp metaforunu kullanmaktadırlar (Brierley, 1995: 139). Bu doğrultuda, hayatın her alanında insanların düşüncelerini yönlendiren anlamlar üretildiği ve bu işaret ya da imgelerin bireyleri anlamlandırmaya çalıştığı söylenebilir. Metafor kullanımı bu bağlamda tüketicilerde reklama ilgiyi arttırmaktadır. Tüketicilerin karışık mesajlarla ilgili belli bir sonuca varabilmesi için değerlendirme yapmaları gerekmektedir.

Böylece, tüketicilerin metafor içermeyen reklamlara göre metafor öğelerini kapsayan reklam mesajlarını algılamaya daha yatkın ve bu mesajların ikna edici olduğunu söylemek mümkündür. Toplumsal yaşamı şekillendiren görüşler, inançlar, işaretler, simgeler ve dil aracılığıyla bireylerin anlamlandırılmasına yön vermektedir.Metaforlar, firmalar için tüketicilerin dikkatini çekebilmek için en uygun vasıtalardır. Markaların reklam çalışmalarında kullandığı metaforlar, tüketiciler tarafından yorumlanma ve algılanma şeklini ve mesajı verilen ürüne verilen değeri büyük ölçekte etkilemektedir.

\section{TV Reklamlarına Yönelik Bir Alan Araştırması}

Çalışmanın bu bölümünde araştırma amaçlarının gerçekleştirilmesi için izlenen yolun ayrıntılı bir açıklaması yapılmıştır. Aşağıda sırasıyla araştırmanın hangi amaçla yapıldığı ve nasıl bir önem taşıdığı, araştırmanın hangi yöntemle gerçekleştirildiği ve nasıl bir model içerdiği, çalışmanın evreni ve örneklemi, araştırmanın kısıtları, verilerin nasıl toplandığı ve çözümlendiğine ilişkin bilgilere yer verilmiştir.

\section{Araştırmanın amacı ve önemi}

Dünya ölçeğinde olduğu gibi yerele özgü hareket etmenin önemini anlayan global markalar, reklamın da dahil olduğu pazarlama iletişimi çalışmalarında ürün, içerik, mesaj gibi konularda daha duyarlı bir yaklaşım göstererek yerel tüketici merkezli hareket etmeye çalışmaktadırlar. Her ne kadar dünya küresel bir köye dönüşmüş olsa bile markaların her yerel bölge için aynı mesaj doğrultusunda farklı iletişim stratejileri oluşturması zorunlu hale gelmiştir. Markaların global pazarlarda varlığını sürdürebilmesi için glokal reklamlara yönelmesi ve burada da reklam kampanyalarının uygulandığı ülkelerde yerel iç görülerle iletişimlerini yeniden gözden geçirmesi, bu hususta göz önünde bulundurmaları gereken glokal reklam stratejileri çalışmanın ana eksenini oluşturmaktadır. Global markaların yerel tüketicilerin ilgisini çekmek ve reklamın çekiciliğini artırmak üzere metafor kullanımına başvurdukları gözlemlenmesi bu konuda araştırma yapmaya itmiştir. 
Bu araştırmanın temel amacı, global markaların Türkiye'de yayımlanan TV reklamlarında metafora ne şekilde yer verdiğini, tüketicinin reklamdaki metaforu nasıl algıladığını ortaya koymaktır. Bu araştırmada amaç aynı zamanda kullanılan metaforların tüketici nezdinde global markalara ilişkin algıyı nasıl etkilediğini ve global markaların glokal reklamlarda yerel kültüre ilişkin göstergelere yer verip vermediğini saptamaktır. Çalışmada bu temel amacı gerçekleştirebilmek için şu sorulara yanıt aranmaktadır:

- İzleyen tüketicilerin reklama ilişkin mesaj ve duygusal çağrışımlara ilişkin değerlendirmeleri nasıldır?

- İzleyen tüketiciler, reklamlarda kullanılan metaforların reklama sunduğu katkı hakkında ne düşünmektedirler?

- Reklamda kullanılan metaforlar, tüketicilerin markalara ilişkin algısını ne yönde değiştirmektedir?

- Reklamda yer verilen yerel kültüre özgü göstergeler, izleyenler tarafindan nasıl algılanmaktadır?

Bu araştırma temel itibariyle, global markalar tarafından Türkiye'deki TV kanallarında yer verilen reklamlarda kullanılan metaforlara ve yerel kültürel göstergelere ilişkin izleyenler tarafından nasıl bir algı oluştuğunun çözümlenmesi bakımından önemli bir rol oynamaktadır. Bu konuda bilimsel çalışmalara pek de rastlanılmaması nedeniyle tüketicilerin metafor konusundaki algılarının tespiti açısından faydalı olacağı düşünülmektedir.

\section{Araştırmanın yöntemi ve modeli}

Çalışmada markaların glokalizasyon stratejilerini reklamlar üzerinden nasıl kullandıkları incelenmektedir. Bu bağlamda, global markaların Türkiye'de yayımladıkları reklam filmlerinde Türk halkına ve kültürüne ait söylemler nitel çözümlemelerle irdelenmektedir. Araştırma nitel araştırma yöntemi kapsamında odak grup tekniğiyle gerçekleştirilmiştir. Nitel araştırma yöntemleri bireylerin algılamaları, tecrübe ve davranışlarını incelemektedir. (Yengin, 2017: 40). Nitel araştırma herhangi bir nokta üzerinde odaklanmada, araştırma problemine yorumlayıcı yaklaşımı kapsayan bir yöntem olarak tanımlanmaktadır (Altunışık vd. 2004: 213). Odak grup tekniği hem gözlem hem de derinlemesine mülakat yöntemlerinin üstünlüklerinden faydalanma amaçlı olarak oluşturulmuştur. Grup oluşturulduktan sonra tartışmalar araştırmacı tarafından yönlendirilmiştir. Metafor kavramının glokal reklam çalışmalarında kullanımı ve literatür ile özdeşleşir bir biçimde betimlenmesini incelendiği bu çalışma nitel araştırma yöntemlerine uymaktadır.

Çalışmada TV reklamlarında kullanılan metaforların tüketicilerin markaya ilişkin algısı tespit edilmeye ve tanımlanmaya çalışılmıştır. Dolayısıyla araştırmanın modeli, tanımlayıcı araştırma modelidir. Karasar (2000: 76) tanımlayıcı modeli, geçmişte ya da halen var olan bir durumu, olayı var olduğu şekliyle betimlemeyi amaçlayan temel araştırma yaklaşımı olarak ele almaktadır. Bu 
çalışmada önce metafor içeren reklamlar belirlenmiş, akabinde o reklamlar çerçevesinde izleyicilerle metaforların çağrıştırdıkları üzerine görüşmeler yapılmıştır. Dolayısıyla araştırma, hem durumların hem de düşünce ve algıların (metaforlara ilişkin izleyici algılarının) olduğu gibi ortaya konulduğu bir durum saptama çalışmasıdır. Çalışmada nitel araştırma deseni doğrultusunda, odak gruba metafor içeren televizyon reklamları izlettirilerek bir görüşme formu çerçevesinde derinlemesine görüşme tekniği uygulanmıştır. Toplamda 6 global markadan, Türkiye'de yayımlanan 12 televizyon reklamı izlettirilmek için seçilmiştir. Derinlemesine görüşme sürecinde izlettirilen reklamlar, global markaların Türkiye'de yayımladığı reklam filmleri göz önünde bulundurularak, içinde metafor olup olmadığı saptanıp amaçlı örnekleme metoduyla seçilmiştir.

\section{Araştırmanın sınırlııkları}

Bu çalışma, global markaların Türkiye'deki ulusal kanallarda yayımladıkları TV reklamlarının tüketiciler üzerinde oluşturdukları algı ve çağrışımların belirlenmesiyle ilgilidir. Zaman ve maliyetten ötürü bütün reklamlar ve tüm iletişim araçları üzerine bir araştırma yapmak mümkün görünmemektedir. Dolayısıyla 2017 yılında Türkiye'deki ulusal TV kanallarındaki, örneklem dahilindeki metaforik anlatım içeren, kuşak reklamlar tercih edilmiştir. Bu, araştırmanın ilk sınırlıı̆ı̆ıdır. Araştırmanın ana kütlesini tüm global markaların reklamları oluşturmaktadır. Çok geniş olması nedeniyle, örneklemin belirlenmesinde karşılaşabilecek zorluk göz önüne alınarak, metaforik anlatım içeren altı global markanın reklamlarının ele alınmasına karar verilmiştir. Bu da, araştırmanın bir diğer sınırıdır. Araştırma yönteminin nitel araştırma desenine göre uygulanması nedeniyle sayısal olarak verilerin alınmaması, odak grubu tekniğinden ötürü seçilen reklam kayıtlarını izlemeyi ve kendisiyle görüşme yapılmasını kabul eden izleyicilerle sınırlıdır.

\section{Evren ve örneklem}

Bu araştırmanın evreni, 2017 yılında Türkiye'de faaliyet gösteren global markaların YouTube video platformunda yayımlanan tüm reklamlarıdır. Önceden belirlenmiş 6 global markanın 2017 yılında Türkiye'deki televizyon kanallarında yayımlanmış, YouTube üzerinden derlenerek seçilen reklamları, araştırmanın örneklemini teşkil etmektedir. Bir yıl içerisinde tüm televizyon kanallarında yayımlanmış olan reklamların tamamının üzerinde çalışılması, zahmetli ve zaman alıcı olmanın ötesinde, örneklem mantığı açısından da gereksiz görülmüştür. Bunun yerine 2017 yılının ayları arasından bir örneklem alınması ve örnekleme giren aylarda yayımlanan "kuşak reklamları" üzerinde çalışılmasına karar verilmiştir. Sonuç itibariyle araştırmada örneklem adına Tablo 1'de gösterildiği üzere, 6 global markanın her birinden 2 reklam seçilerek toplamda 12 reklam çalışması üzerinde durulmuştur. 
Tablo 1. Örneklem olarak seçilmiş TV reklamlarına ait bilgiler

\begin{tabular}{ll}
\hline Marka Adı & \multicolumn{1}{c}{ Seçilen Reklamlar } \\
\hline \multirow{2}{*}{ Coca Cola } & $\begin{array}{l}\text { 1. Usul Usul Yeme Modu Lahmacun Reklamı } \\
\text { 2. Köftelerin Gücü Adına }\end{array}$ \\
\hline \multirow{2}{*}{ Elidor } & $\begin{array}{l}\text { 1. Güç Doğamızda Var } \\
\text { 2. Esmer Parlaklık }\end{array}$ \\
\hline \multirow{2}{*}{ Burger King } & $\begin{array}{l}\text { 1. Burger King Mehter } \\
\text { 2. Big King Menü }\end{array}$ \\
\hline \multirow{2}{*}{ McDonald's } & $\begin{array}{l}\text { 1. Max Burger Türk Usulü Hamburger } \\
\text { 2. Başka Acıya Gerek Yok }\end{array}$ \\
\hline \multirow{2}{*}{ odafone } & $\begin{array}{l}\text { 1. Beyazıt Öztürk Ramazan Reklamı } \\
\text { 2. Bucak G Reklamı }\end{array}$ \\
\hline
\end{tabular}

\section{Verilerin toplanması}

Veri toplama tekniği olarak isstanbul Aydın Üniversitesi Halkla ilişkiler ve Tanıtım Bölümü ve Programı olmak üzere, lisans ve önlisans öğrencilerini kapsayacak şekilde 14 kişi ile odak grup görüşmesi sağlanmıştır. Araştırma kapsamında verilmek istenen mesaj, reklamlar aracılığıyla çağrışım yapan duygular, reklamlarda gerçek anlamı dışında kullanılan görsel ve sözel öğeler, izleyicilerin reklamlarda kullanılan metaforları nasıl algıladığı, yerel kültüre ilişkin göstergeleri nasıl anlamlandırdığı, reklama ilişkin duygu ve düşünceler olmak üzere toplamda yedi soru katılımcıya iletilmiştir. Toplamda 6 global markanın Türkiye'de gerçekleştirmiş olduğu ve yerel kültüre özgü göstergeler ile metaforların karakteristik özelliklerini ortaya çıkarmak amacıyla glokal reklam çalışmaları tek tek izlettirilmiştir. İzlenilen reklamlardaki yerel kültürel kodların ve metaforların tüketiciler tarafından nasıl algılandığına ilişkin veriler tasarlanmıştır. Bu verilerin toplanmasında izleyiciler, reklamlarda kullanılan metaforlar ile yerel kültürel kodları değerlendirmiş ve kodlayıcıların global markaların glokal reklam çalışmalarının marka imajına etkisi hakkında düşünceleri saptanmıştır. Bu verilerin toplanmasında, metafor içeren reklamların reklamları izleyen kişilerle "yarı yapılandırılmış görüme" yapılmıştır.

Nitel araştırmalarda görüşme, temel veri toplama araçlarından biri olarak kabul edilmektedir. Görüşme genel itibariyle belli şartlar altında tasarlanmış, belli bir amaca yönelik soru sorma ve cevap alma sürecine dayalı karşılıklı ve etkileşimli bir süreç olarak tanımlanmaktadır (Yıldırım ve Şimşek, 2006: 119). Görüşme, insanların olaylara ve olgulara nasıl baktıklarına ilişkin algı, anlamlandırma ve tanımlamalarını anlamanın bir tekniğidir (Punch, 2005: 165-166). Görüşme sayesinde, görüşmeciye esneklik sağlanması, görüşülen kişinin davranışlarını ve anlık tepkilerini gözlemleyebilme olanağı tanınması, konuyla ilgili 
derinlemesine bilgiye ulaşılabilmesi yer almaktadır (Yıldırım ve Şimşek, 2006: 123).

\section{Bulgular ve Tartışma}

İzleyici deneklerin reklamda verilmek istenen mesajın ne olduğuna dair sorulan soruya vermiş oldukları yanıtlar arasında en çok tekrar edilen fikirler "lahmacunun verdiği hararetin Coca Cola'nın söndürmesi" olmuştur. Dolayısıyla, Coca Cola "her zaman, her yemeğin yanında bulundurulması gereken bir içecek" olarak sunulmuştur. Coca Cola'nın ikinci reklamına bakıldığında ise, içeceğin köfte ile bağdaştırıldığı, şişenin arkasında görünen melek kanatlarının verdiği mesaj ise Coca Cola'nın "her zaman iyilerin yanında olduğu" anlamına gelmektedir. Elidor markasının "güç doğamızda var" reklamına gelen yanıtlar incelendiğinde genel olarak doğa ile kadın gücünün karşılaştırıldığı ve kadının gücünü yansıtan, onları güçlü hissettiren olumlu duyguların oluştuğu görülmektedir. "Esmer Parlaklık" reklamında verilmek istenen mesajı ise esmer kadınların bir ortamda söz sahibi olduğu, "Elidor kullanırsanız siz de onlar gibi cazibeli olacaksınız" şeklinde yorumlanmıştır.

Burger King'in "Mehter" reklamına ilişkin izleyicilerde oluşan algı incelendiğinde, "menünün yeniçeriyi bile doyurabileceğine" ilişkin değerlendirmeler gözlemlenmektedir. Markanın izlettirilen ikinci "Big King Menü" reklamının verdiği mesajlarda seslenen fikirler "Burger King ile bütünleşmek", "imparatorluk" ve aynı zamanda markaya ayrıcalık yükleyen ifadelerin de yer aldığı görülmektedir. McDonald's "Max Burger Türk Usulü Hamburger" reklamının verdiği mesajın konusu küreselleşme, markanın sunduğu yiyeceklerin her kültüre uyum sağladığı, ayrıca Türklerin her yerde kendine has duruşu olduğu şeklindedir. Markanın "Başka Acıya Gerek Yok" isimli reklam çalışması ise, hamburgerin acısının kalan bütün acıların en başında geldiği şeklinde algılanmaktadır.

Vodafone'un "Beyazıt Öztürk Ramazan Reklamı"na gelen yanıtlarda bir izleyicinin soruyu cevaplandırmadığı görülmektedir. Diğer izleyicilerde reklamın oluşturduğu algı; Ramazan ayına has birlik, beraberlik, dayanışma, yardımlaşma ve kardeşlik olmuştur. Markanın ikinci "4 Bucak G" reklamında verilmek istenen mesajlar katılımcılar tarafından operatörün Türkiye'nin dört bir tarafını çekim gücü ile birleştirdiği, insanlarda bayram havası uyandırdığı şeklinde algılanarak karşımıza çıkmaktadır. PepsiCo markasından izlenilen birinci "Ruffles" reklamının izleyicilerde oluşturduğu anlam, diğer cipslere oranla Lay's cips paketlerinin içeriğinin daha dolu olması şeklinde olduğu gözlemlenmektedir. ikinci "Ayşe Teyze'li Lay's" reklamında verilmek istenen mesajı incelediğimizde; Ege'nin marka gözünde ne kadar değerli olduğu, doğal zeytin yağı kullanımının gösterilmesi, güvenilir bir marka olduğu söylenebilir.

Reklamı izledikten sonra reklamın denek izleyicilerde ne tür duygular oluşturduğu sorulduktan sonra alınan yanıtlar incelendiğinde, araştırma kapsamına giren çoğu markanın tüketicilerde oluşturduğu ortak duygular; mutluluk, 
milliyetçilik, vatanseverlik ve eğlence olarak göze çarpmaktadır. Burada her bir global markanın mutlaka yerel kültüre ait yemek, davranış biçimi, müzik vb. unsuruna yer vermesine önem verdiği gözlemlenmektedir. İncelenen reklamların 4'ünde milliyetçilik ve vatanseverlik, 5 'inde ise mutluluk duyguları çağrıştırılmıştır. Onları sırasıyla da özgürlük ve güçlü olmak takip etmektedir. Dolayısıyla buradan alınan veriler doğrultusunda duygusal çekiciliklerin ağırlık kazandığı söylenebilir.

Tüketicilere izledikleri reklamlarda gerçek anlam dışında kullanılan görsel ve sözel öğelerin neler olduğuna dair sorulan soruya verilen yanıtlara genel olarak bakıldığında ise, deneklerden reklamları anlamlandırılması istendiğinde, örnekleme giren tüm reklamların gerçek anlamı dışında kullanılan görsel ve sözel öğelerin varlığından bahsetmektedirler. Bu tip öğelerin bulunmasıyla izleyici deneklerin dikkatinin daha kolay bir şekilde çekildiği saptanmıştır.

Deneklere reklamlarda kullanılan metaforlarla ilgili, bunların markaya ilişkin algıları ve üzerindeki etkilerinin neler olduğu, yerel kültürel göstergelerin reklamın yaratıcılığına katkısı ve reklam mesajıyla örtüşmesine ilişkin sorular sorulmuştur. Katılımcılardan alınan yanıtlarda, literatürde değinilen metafor türlerinden; soyut metafor, somut metafor, ontolojik metafor, ölü metafor gibi türlerle karşılaşıldığı anlaşılmaktadır. Örneklem olarak seçilen reklamlar için metafor kullanımının kodlayıcı ile araştırmacı arasındaki tutarlılığın denekler arasında da sürmesi göze çarpmaktadır. Aynı zamanda araştırmaya katılan izleyici deneklerin tüm reklamlar için metafor kullanımına ilişkin olumlu görüşleri gözlemlenmektedir. İzleyici denekler, metafor kullanımının 11 reklam için yaratıcılığı önemli ölçüde etkilediği ve verilmek istenen mesajla bütünleştiği konusunda hem fikir olmuşlardır.

Reklamı izledikten sonra denek izleyicilere, reklamda yerel kültüre ilişkin hangi göstergelerle karşılaştıkları ve bu göstergelerin reklamın mesajıyla bütünleşip bütünleşmediği sorulmuştur. Alınan bulgulara göre örneklem kapsamındaki 10 reklamda izleyici denekler tarafından yerel kültüre özgü unsurların varlığından bahsedilmiştir. Bu unsurlar içerisinde ülkemize özgü yemekler olarak lahmacun, köfte; malzeme olarak masa örtüsü, mangal; eşya olarak yerel kıyafetin yanında yöresel dil, Türk bayrağı, müzik gibi göstergeler dikkat çekmektedir. Tüketicilere izledikleri reklamlara ilişkin zihinlerinde oluşan çağrışımların neler olduğuna dair sorular sorulduktan sonra alınan bulgular doğrultusunda, her bir reklam için tüketicinin zihninde belli çağrışımların oluştuğu dikkat çekmektedir.

\section{Sonuç}

Günümüzde ekonomik yaşamın önemli aktörleri olan şirketlerin yoğun rekabet ortamında varlıklarını sürdürebilmeleri ve rakiplerinden farklılaşabilmeleri açısından hedefleri doğrultusunda iletişim çalışmalarına geniş yer ve değer vermeleri önem kazanmaktadır. Uluslararası pazarlamada bir iletişim aracı ola- 
rak reklamların, çeşitli pazarlarda ürünün/hizmetin tutundurulması için stratejik olarak kullanılması gerekmektedir. Ülkeler reklamcılıkla ilgili çalışmaların uygulama sürecinde önemli bir etkiye sahip olan kendi, yerel özelliklerine sahiptir. Bugünün pazar ortamında reklamcılığın temel amacı, pazarlama iletişim sisteminin temel hedeflerine, yani talep yaratma ve satış tutundurmaya, ulaşmayı amaçlamaktadır. Dünyada ekonomik, politik ve kültürel entegrasyon ile birleşme süreci olarak globalizasyon, bilgi ve telekomünikasyon teknolojilerinin gelişmesinin bir sonucudur. Globalleşme sürecine ulus ötesi şirketlerin global ölçekte güçlü faaliyetleri, konsantrasyon ve tekelleşme süreçlerinde artış, global medya ve global bilgi değişiminin hızlandırılması, farklı kültürlerin iç içe geçmesi ve ortak kültürel standartların tanıtılması gibi bir dizi faktörler ön plana çıkmaktadır.

Globalizasyon çağında iletişim ve bilgisayar alanında yaşanan teknolojik gelişmelerin yanı sıra, sınırların ortadan kalktı̆ı̆ tek bir dünya pazarından bahsetmek mümkündür. Globalizasyon toplumsal, siyasal, kültürel ve ekonomik anlamda ortaya çıkardığı değişimlerle, pazar yapısını ve firmaların pazarlama anlayışlarını da değiştirmiştir. Bu bağlamda işletmeler için önemli bir anlamı olan reklamların gerekli etkiyi yaratabilmesi, reklamların ulaşması gereken hedef kitlenin beklentileri doğrultusunda, kültürel özelliklerinin doğru bir şekilde tespit edilmesine; hedef kitlenin kültürel, yerel değerlerine uygun şekilde seçilmesine bağlıdır. Hedef kitlelerin yaşadıkları farklı ülkeler ve coğrafi bölgeler, reklamın hedef aldığı izleyicilerin sahip olduğu kültürel değerler, yaşam biçimleri, gelenek ve görenekleri arasındaki farklılıklar işletmeler açısından önem taşımaktadır. Bu anlamda glokal reklam çalışmalarında ülkelerin toplumsal değerleri, farklı kültürel yapısına uygun olan çalışmaların hazırlanması ve hedef kitlenin ait olduğu coğrafi bölgelere özgü yerel içeriklere yer verilmesi, glokal reklam çalışmalarının başarısını doğrudan etkileyen bir faktördür. Dolayısıyla glokal reklamlar, hitap ettiği kesimle ürün, hizmet, kurum veya markanın sürekli iletişim içinde olduğu bir ortamdır.

Günümüzde teknolojinin hâkimiyeti göz önüne alındığında tüketici ile etkileşimin ön plana çıkması sonucunda, bireyselleşen müşteri ve onun davranışlarını anlamak glokal reklam çalışmalarında zorunlu hale gelmektedir. Yaşadığı coğrafyaya, ait olduğu kültüre göre bireyselleşmiş tüketici, yaşamını kendi kontrolü altında tutan, diğer bireylerden kendine has özellikleriyle farklı tüketim şekilleri gösterebilmektedir. Bu bağlamda uluslararası pazarlara yönelik reklam mesajlarının sunulacağı o bölgenin kültürel yapısına uygun biçimde oluşturulması, reklam mesajların hedef kitle tarafından doğru algılanması reklamcıların ve markaların göz önünde bulundurması gereken bir zorunluluktur.

Bu araştırmada altı global markanın Türkiye'de 2017 yılında ulusal televizyon kanallarında yayımladıkları metafor içeren glokal reklam çalışmaları incelenmiştir. Coca Cola, Burger King, Elidor, McDonald's, Vodafone ve PepsiCo markalarının (Ruffles ve Lays) her birinden yerel kültüre özgü, Türkiye'ye uyar- 
lanmış iki glokal reklam çalışması seçilmiştir. Çalışmada, televizyon kanallarında gösterilen bu 12 reklamda kullanılan yerel-kültürel öğelerin ve metaforların izleyiciler tarafından nasıl algılandığının ve bunun markaya ilişkin algıları nasıl etkilediği konusundaki değerlendirmelerin ortaya konulması amaçlanmıştır.

Reklam mesajlarının izleyici deneklerde oluşturduğu duyguları saptamak için sorulan sorulara baktığımızda, Coca Cola'nın “Usul Usul Yeme Modu Lahmacun Reklamı"na gelen yanıtlara göre reklamın, izleyicilerin çoğunda açlık duygusu ve dolayısıyla satın almaya yönlendirme duygusu uyandırdığı dikkat çekmiştir. Markanın ikinci "Köftelerin Gücü Adına" reklamının izleyen deneklerde çağrıştırdığı duyguların ise yine açlık ve susuzluk duyguları olduğu söylenebilir. Elidor'un "Güç Doğamızda Var" reklamına yönelik yanıtlar kadınlarda özgüven duygusu uyandırdığı, kadınların her türlü zorluğun üstesinde gelebildiği şeklindedir. "Esmer Parlaklık" reklamı ise izleyici denekleri enerjik hissettirmiş, eğlence, mutluluk, dans etme isteği uyandırmıştır.

Burger King markasının "Burger King Mehter" reklamı izleyicilerde mehter marşının katmış olduğu milli duyguları uyandırdığı görülmektedir. Aynı zamanda "her hangi bir çağrışımda bulunmadığı" ve "fazla yapmacık bir reklam olduğu" şeklinde değerlendirilmiştir. Yine aynı markanın "Big King Menü" reklamına gelen yanıtlar incelendiğinde daha çok açlık hissi uyandırdığı, bir an önce menüyü satın alma duyguları oluştuğu görülmektedir. McDonald's reklamlarının izleyicilerde çağrıştırdığı duyguların neler olduğu incelendiğinde "Max Burger Türk Usulü Hamburger"in espirili bir dille anlatıldığı, Türklüğün ve milli duyguların önde olduğu şeklinde değerlendirildiği söylenebilir. "Başka Acıya Gerek Yok" reklamı ise büyük çoğunlukta açlık duygusu ve menüyü deneme isteği çağrşıştırmıştır.

Vodafone'dan izlettirilen "Beyazıt Öztürk Ramazan Reklamı" izleyenlerin çoğunda "birlik, beraberlik", "Ramazan ayının güzelliği" gibi olumlu duyguları uyandırmıştır. Markaya ait "4 Bucak G" reklamı ise "memleket sevgisi", "özlem", "birlik", "bütünlük" duyguları çağrıştırmıştır. PepsiCo Ruffles reklamının izleyenlerde ne tür duygular uyandırdığı sorusunu bir denek "Hiçbir şey hissetmedim" şeklinde yanıtlamıştır. Diğer yanıtlar incelendiğinde reklamın "enerjik", "eğlenceli", "mutluluk verici" şeklinde değerlendirildiği söylenebilir. "Ayşe Teyze'li Lay's Reklamı"nın uyandırdığı duygular; "Ayşe Teyze" karakterinin Türk kültürünü yansıtmasından dolayı eğlenceli, komik, olumlu duygular uyandırdığı şeklinde olduğu görülmektedir.

Araştırma kapsamında reklamlarda kullanılan metaforların türleri ve bunun marka algısını nasıl etkilediğine dair sorulan soruya verilen yanıtlar incelendiğinde; ontolojik, soyut ve somut metafor türlerine yer verildiği söylenebilir. Türk kültürüne ilişkin sözel ve görsel öğelerin reklamlarda yeterince yer verildiği ve verilmek istenen reklam mesajıyla bütünleştiği gözlemlenmektedir. İzleyici denekler bazı soruları yanıtsız bıraksa da, görüşlerin genel olarak 
bir noktada kesiştiği söylenebilir. Kullanılan yöresel dil, kıyafetler, tümceler ve metaforlar reklamları daha yaratıcı olması konusunda orta düzeyde bir uyuşma olduğu gözlemlenmektedir. Metaforların reklamdaki rolünü değerlendirirken, genel görüşlerin marka algısını olumlu yönde değerlendirdiği, yöresel dil, kıyafet ve müziğin reklamı daha eğlenceli hale getirdiği ve izlemeye değer bir çalışma olduğu göze çarpmaktadır. Araştırılan reklamlarda kullanılan metaforlar daha çok birlik, beraberlik çağrıştırdığı; yöresel oyunların, kullanılan karakterlerin, kıyafetlerin, yöresel dilin reklamlara yaratııılık kattığı saptanmıştır.

\section{Kaynakça}

Altunışık, R., Coşkun, R., Bayraktaroğlu, S., Yıldııım, E. (2004). SPSS Uygulamalı Sosyal Bilimlerde Araştırma Yöntemleri. Sakarya: Sakarya Kitabevi.

Ang, S. H., Ali, E., Lim, C. (2006). "The Influence of Metaphors and Product Type on Brand Personality Perceptions and Attitudes". Journal of Advertising. 35(2). 39-53. doi: 10.1080/00913367.2019.1585305.

Arslan, K. (2016). “Global Pazarlama Glokal Pazarlama ikilemi Çerçevesinde Glokal Pazarlama Anlayışının Geleceği". Akdeniz Üniversitesi Iktisadi ve İdari Bilimler Fakültesi Dergisi. 33. 63-78.

Balcı, A. (2006). "Roland Robertson, Küreselleşme ve Kültür". Bilgi. 12. 25-36.

Baudrillard, J. (2008). Tüketim Toplumu. (H. Deliceçaylı ve F. Keskin, çev.). İstanbul: Ayrıntı Yayınları.

Brierley, S. (1995). The Advertising Handbook. London: Routledge.

Champy, J. (1997). "Think Globally, Sell Locally". Sales/Marketing Management. Temmuz. 24-25.

Chiu, C. Y., Kwan, L. Y., Li, D., Peng, L., Peng, S. (2012). “Culture and Consumer Behaviour". Foundations and Trends in Marketing. 7(2). 109-179. doi: $10.1561 / 1700000052$.

Elden, M. (2005). "Glokal Reklam Kampanyalarında Yaratııılığın Önemi”. Bilig. 32. 65-82.

Eraslan, L. (2011). "Sosyolojik Metaforlar". Akademik Bakış Dergisi. 27. 1-22.

Fiske, J. (2003). iletişim Çalışmalarına Girişs. (S. İrvan, çev.). Ankara: Bilim ve Sanat Yayınları.

Forceville, C. (1996). "Pictorial Metaphor in Advertising". Metaphor and Symbolic Activity. 9(1). 1-29.

Karamehmet, B. (2012). Kuramsal iletişimde Metafor. İstanbul: Beta Yayınları.

Karasar, N. (2000). Bilimsel Araştırma Yöntemi. Ankara: Nobel Yayın.

Kazançoğlu, i., Ventura, K., Baybars, M., Tatlıdil, R. (2011). “Niş Pazarlara Özgü Glokal Ürün Stratejilerinin Geliştirilmesi: Tchibo Türkiye Örneği". Dokuz Eylül Üniversitesi Işletme Fakültesi Dergisi. 12(1). 67-82. 
Kellner, D. (2001). “Popüler Kültür ve Postmodern Kimliklerin İnşası”. (G. Seçkin, çev.). Doğu-Batı Düşünce Dergisi. 4(15). 187-219.

Khondker, H. (2004). “Glocalization as Globalization: Evalution of a Sociological Concept". Bangladesh e-Journal of Sociology. 1(2). 12-20.

Kövecses, Z. (2010). Metaphor: A Practical Introduction. New York: Oxford University Press.

Lakoff, G. (1993). "The Contemporary Theory of Metaphor". A. Ortony (ed.) Metaphor and Thought. (202-251). London/New York: Cambridge University Press.

Lakoff, G. ve Johnson, M. (2003). Metaphors We Live By. London: The University of Chicago Press.

(2005). Metaforlar: Hayat, Anlam ve Dil. (G. Y. Demir, çev.). İstanbul: Paradigma Yayınevi.

Maynrad, M. L. (2003). "From Global To Local: How Gillette's Sensor Excel Accomodates to Japan”. Keio Communication Review. 25. 57-78.

Morgan, S. E. ve Reichert, T. (1999). "The Message is in the Metaphor: Assessing the Comprehension of Metaphors in Advertisements". Journal of Advertising. 28(4). 1-13. doi: 10.1080/00913367.2019.1585305.

Nietzsche, F. (2002). Güç Istenci: Bütün Değerleri Değiştiriş Denemesi. (S. Umran, çev.). İstanbul: Birey Yayınları.

Okay, A. S. (2015). Kültür Emperyalizmi Bağlamında Glokal Reklam. (Yayımlanmamış Yüksek Lisans Tezi). Erzurum: Atatürk Üniversitesi Sosyal Bilimler Enstitüsü.

Pawlowski, D. R., Badzinski, D. M., Mitchell N. (1998). “Effects of Metaphors on Children's Comprehension and Perception of Print Advertisements". Journal of Advertising. 27. 83-98. doi: 10.1080/00913367.2019.1585305.

Punch, K. F. (2005). Sosyal Araştırmalara Giriş. Nicel ve Nitel Yaklaşımlar. (Z. Akyüz, D. Bayrak, H. B. Arslan, çev.). Ankara: Siyasal Kitabevi Yayınları.

Robertson, R. (1999). Küreselleşme: Toplum Kuramı ve Küresel Kültür. (Ü. H. Yolsal, çev.). Ankara: Bilim ve Sanat Yayınları.

(2011). "Glokalleşme: Zaman-Mekan ve Homojenlik-Heterojenlik". (M. F. Elmas, çev.). Kaygı. 17. 185-202.

Salman, Y. (2003). “Dilin Düşevreni: Eğretileme”. Kitap-lık, Aylık Edebiyat Dergisi. 109. 53-65.

Sığırcı, İ. (2016). Göstergebilim Uygulamaları. Ankara: Seçkin Yayıncılık.

Yaman, A. (2015). Reklamda Ses ve Müzik Kullanımı. (Yayımlanmamış Yüksek Lisans Tezi). İstanbul: İstanbul Bilgi Üniversitesi Sosyal Bilimler Enstitüsü.

Yengin, D. (2017). iletişim Çalışmalarında Araştırma Yöntemleri ve Uygulamaları. İstanbul: Der Yayınları.

Yıldırım, A. ve Şimşek, H. (2006). Sosyal Bilimlerde Nitel Araştırma Yöntemleri. Ankara: Seçkin Yayınları. 
Yıldırım, E. (2001). "Metaforlar ve Toplam Kalite Yönetimi". 9. Ulusal Yönetim ve Organizasyon Kongresi. 25-28 Mayıs 2001. İstanbul.

Zaltman, G. (2003). Tüketici Nasıl Düşünür?. (A.Semih Koç, çev.). isstanbul: MediaCat Yayınları.

Ziss, A. (1984). Estetik: Gerçekliği Sanatsal Özümsemenin Bilimi. (Y. Şahan, çev.). ìstanbul: De Yayınevi. 